GRASAS Y ACEITES 67 (2)

April-June 2016, e130

ISSN-L: 0017-3495

doi:http://dx.doi.org/10.3989/gya.0630152

\title{
Fatty-acid alkyl esters in table olives in relation to abnormal fermentation and poorly conducted technological treatments
}

\author{
B. Lanza ${ }^{\bowtie}$, M.G. Di Serio and L. Di Giacinto \\ Council for Agricultural Research and Economics (CREA). CREA-OLI Olive Growing and Oil \\ Industry Research Centre. Viale Petruzzi 75, 65013 Città Sant'Angelo (PE), Italy \\ ${ }^{\square}$ Corresponding author: barbara.lanza@entecra.it
}

Submitted: 11 June 2015; Accepted: 23 November 2015

SUMMARY: There are several methods to prepare table olives, and each of the steps and conditions during this processing can affect the composition and nutritional value of the product. The influence of abnormal fermentation and poorly conducted technological treatments was examined here in terms of the lipid fraction of table olives. In 'Greek style' olives, a low concentration of brine can allow the growth of spontaneous microflora and consequent organoleptic defects ('putrid/butyric fermentation', 'winey-vinegary'). Here, the 'Kalamata' and 'Moresca' cultivars can produce methyl esters (methyl oleate/ linoleate: 553 and $450 \mathrm{mg} \cdot \mathrm{kg}^{-1}$ oil, respectively) and ethyl esters (ethyl oleate/ inoleate: 4764 and 4195; palmitate: 617 and $886 \mathrm{mg} \cdot \mathrm{kg}^{-1}$ oil, respectively). In 'Sevillan style' olives, a high $\mathrm{NaOH}$ concentration influences the fatty-acid composition less, but is difficult to eliminate, for a 'soapy' defect. The 'Giarraffa' and 'Nocellara del Belice' cultivars produce only ethyl esters (ethyl oleate/ linoleate: 222 and $289 \mathrm{mg} \cdot \mathrm{kg}^{-1}$ oil, respectively). With this production of ethyl and methyl esters from the principal fatty acids in the lipid fractions of table olives, methods that provide only biological treatments (i.e., Greek style) pose more risk than methods that provide only chemical treatments (i.e., Sevillan style).

KEYWORDS: Abnormal fermentation; Alkyl esters; Fatty-acid composition; Olea europaea L.; Sensory analysis; Table olives

RESUMEN: Ésteres alquílicos de ácidos grasos en aceitunas de mesa en relación con fermentaciones anormales y tratamientos tecnológicos mal realizados. Hay varios métodos para preparar las aceitunas de mesa, y cada uno de los pasos y condiciones durante este procesamiento pueden afectar a la composición y al valor nutricional del producto. La influencia de la fermentación anormal y tratamientos tecnológicos mal realizadas se examinó aquí en términos de la fracción lipídica de aceitunas de mesa. En las aceitunas procesadas mediante estilo griego, la baja concentración de salmuera permite el crecimiento espontáneo de microflora y la consiguiente aparición de defectos organolépticos ('fermentación butírica y avinagrado'). Los cultivares de 'Kalamata' y 'Moresca' pueden producir ésteres metílicos (oleato y linoleato: 553 y $450 \mathrm{mg} \cdot \mathrm{kg}^{-1}$ de aceite, respectivamente) y ésteres etílicos (oleato y linoleato: 4764 y 4195; palmitato: 617 y $886 \mathrm{mg} \cdot \mathrm{kg}^{-1}$, respectivamente). En las aceitunas procesadas mediante estilo sevillano, la alta concentración de $\mathrm{NaOH}$ influye menos en la composición de ácidos grasos, pero es difícil de eliminar el defecto 'jabón'. Los cultivares de 'Giarraffa' y 'Nocellara del Belice' producen solamente ésteres etílicos (oleato y linoleato: 222 y $289 \mathrm{mg} \cdot \mathrm{kg}^{-1}$ de aceite, respectivamente). Con esta producción de ésteres etílicos y metílicos de los ácidos grasos principales en las fracciones lipídicas de las aceitunas de mesa, los métodos que proporcionan tratamientos unicamente biológicos (es decir, de estilo griego) plantean más riesgos que los métodos que proporcionan tratamientos químicos (es decir, de estilo sevillano).

PALABRAS CLAVE: Aceitunas de mesa; Análisis sensorial; Composición de ácidos grasos; Ésteres metílicos y etílicos de ácidos grasos; Fermentaciones anormales; Olea europaea $L$. 
Citation/Cómo citar este artículo: Lanza B, Di Serio MG, Di Giacinto L. 2016. Fatty-acid alkyl esters in table olives in relation to abnormal fermentation and poorly conducted technological treatments. Grasas Aceites 67 (2): e130. doi: http://dx.doi.org/10.3989/gya.0630152.

Copyright: (C) 2016 CSIC. This is an open-access article distributed under the terms of the Creative Commons Attribution-Non Commercial (by-nc) Spain 3.0 Licence.

\section{INTRODUCTION}

Olives are picked at different stages of maturity, and they are then processed to eliminate the characteristic bitterness caused by their oleuropein glucoside, to make them suitable for human consumption. There are several ways to prepare table olives, but the most widespread methods are known as "natural black olives directly placed in brine in the Greek style" (Balatsouras, 1990), and "treated green olives in brine in the Sevillan or Spanish style" (Garrido Fernandez et al., 1997; Sánchez Gómez et al., 2006).

According to the Trade Standard Applying to Table Olives (IOC, 2004), natural olives are "Green olives, turning color olives or black olives placed directly in brine, where they undergo complete or partial fermentation, preserved or not by the addition of acidifying agents". The most important industrial preparation for natural black olives is often referred to as the 'Greek-style' because it is traditionally practiced in Greece using the 'Conservolea' cv. (Balatsouras, 1990). Italy has a long tradition of producing natural turning color olives, where they are put directly into brine (60-80 $\left.\mathrm{g} \cdot \mathrm{kg}^{-1} \mathrm{NaCl}\right)$. The brine stimulates the microbial activity for fermentation and reduces the bitterness of the oleuropein. Fermentation of these olives takes a long time because the diffusion of soluble components through the epidermis of the fruit not treated with alkali is slow.

According to The Trade Standard Applying to Table Olives (IOC, 2004), treated olives are "Green olives, turning color olives or black olives that have undergone alkaline treatment, then packed in brine, where they undergo complete or partial fermentation, and preserved or not by the addition of acidifying agents". To obtain the treated green olives in brine, the green fruits are de-bittered with an aqueous $\mathrm{NaOH}$ solution (lye) from $20 \mathrm{~g} \cdot \mathrm{kg}^{-1}$ to $35 \mathrm{~g} \cdot \mathrm{kg}^{-1}$, which mainly depends on the variety. The alkaline treatment hydrolyses the compound that is principally responsible for the bitter taste (i.e., oleuropein). After this alkaline treatment, the olives are washed with water to remove excess lye. Following the water washings, the olives are covered with brine (60-80 $\mathrm{g} \cdot \mathrm{kg}^{-1}$ sodium chloride solution) and left to develop spontaneous lactic fermentation.

Fermentation processes can be controlled through chemical, physicochemical and microbiological approaches, and since 2008, by organoleptic evaluation (COI/OT/MO/Doc.No1. Method for the sensory analysis of table olives). On 25 November,
2011, following Decision No DEC 18/99-V/2011, the International Olive Council adopted a revised version (COI/OT/MO No 1/Rev.2) for sensory evaluation (IOC, 2011).

Each of the steps and conditions of olive processing can affect the composition and nutritive value of the final product, as table olives. Although there have been some studies related to the composition of raw and processed olives during treatments (Baiano et al., 2009; Boskou et al., 2006; Lanza et al., 2010; Malheiro et al., 2012; Pasqualone et al., 2014), little information is available on the changes that the olive constituents undergo in the presence of abnormal fermentation or poorly conducted technological treatments. In the present study, we evaluated the influence of a low concentration of brine (i.e., Greek styled olives) and a high concentration of $\mathrm{NaOH}$ (in lye; modified Sevillan styled olives) on the lipid fraction of table olives from four olive cultivars ('Kalamata', 'Moresca', 'Giarraffa' and 'Nocellara del Belice').

\section{MATERIALS AND METHODS}

\subsection{Plant material and processing}

Olive (Olea europaea L.) fruits from the 'Kalamata' and 'Moresca' cvs. were hand-harvested at their mature-black stage of ripening (in midNovember) when they were suitable for the Greek style preparation. Similarly, the olive fruits from the 'Giarraffa' and 'Nocellara del Belice' cvs. were hand-harvested at their mature-green stage of ripening (in mid-October) when they were suitable for the Sevillan style preparation.

The picked black olives were size graded and processed as natural black olives in brine (Greek style) according to the Trade Standard Applying to Table Olives (IOC, 2004). Fruits of the 'Kalamata' and 'Moresca' cvs. were directly soaked in brine to ferment spontaneously, using a $40 \mathrm{~g} \cdot \mathrm{kg}^{-1} \mathrm{NaCl}$ solution. Dry salt was added at the top of the vessel to maintain the initial concentration. The sodium chloride content was determined by titrating $5 \mathrm{~mL}$ of brine with the standardized silver nitrate solution using potassium chromate as an indicator with a $5 \%(\mathrm{w} / \mathrm{v})$ solution in water, expressing the results in grams of $\mathrm{NaCl}$ per $100 \mathrm{~mL}$ of brine. $\mathrm{pH}$ was monitored throughout the period. The $\mathrm{pH}$ of brine was measured with an Istek $\mathrm{pH}$ Meter 730P model (Istek, Inc. Seoul, South Korea). After 6 months of storage in this brine, the olives were taken for analysis. 
The picked green olives were size-graded and processed as alkaline-treated green olives in brine (Sevillan style) according to the Trade Standard Applying to Table Olives (IOC, 2004). Fruits of the 'Giarraffa' and 'Nocellara del Belice' cvs. were subjected to de-bittering using a lye solution with a high $\mathrm{NaOH}$ concentration $\left(40 \mathrm{~g} \cdot \mathrm{kg}^{-1}\right)$ at room temperature. This alkali treatment lasted for $8 \mathrm{~h}$, until the lye had soaked into two-thirds of the flesh of the fruit. The lye was then poured off and the olives were washed in water several times, over a period of $30 \mathrm{~h}$. After this washing, the olives were covered with brine $\left(60 \mathrm{~g} \cdot \mathrm{kg}^{-1}\right.$ sodium chloride solution) and left to develop spontaneous lactic fermentation. The olives for the analysis were taken immediately after the water washings (before the fermentation) to avoid the effect of the insurgence of abnormal fermentations and focus the attention on the effect of lye on the lipid fraction.

\subsection{Determination of oil content}

The olive oil was extracted from the fruit with petroleum ether 40-70, for $6 \mathrm{~h}$ in a Soxhlet apparatus, using the olive pulp dried in an air oven at $105^{\circ} \mathrm{C}$ for $24 \mathrm{~h}$. The ether was removed by evaporation, and the residual oil was weighed. The oil content was determined by double weight.

\subsection{Extraction of oil}

To extract the oil from raw and treated olives, the fruits $(250 \mathrm{~g})$ were manually de-pitted and triturated with a grinder. The resulting olive paste was warmed in a water bath at $28 \pm 2{ }^{\circ} \mathrm{C}$ for $30 \mathrm{~min}$, and the oil was extracted by centrifugation at $3756 \times \mathrm{g}$ for $30 \mathrm{~min}$ in a refrigerated centrifuge (ALC PK 120R; Thermo Electron Corporation, Waltham, Massachusetts, USA). The resulting supernatant oil was collected with a pipette Pasteur and filtered in the presence of anhydrous sodium sulphate, and then stored in $50-\mathrm{mL}$ plastic tubes (Falcon) wrapped with aluminum foil and kept at $4{ }^{\circ} \mathrm{C}$ until analysis. This procedure simulates the extraction of olive oil in olive mills (i.e., crushing, mixing and centrifugation) and was used to prevent changes in the oil quality as best as possible.

\subsection{Determination of oil quality indices}

Several criteria were regularly monitored to assess and quantify any changes in the oil quality. These criteria included: free acidity, as the percentage of oleic acid $\left(\mathrm{g} \cdot 100 \mathrm{~g}^{-1}\right)$; the peroxide value, as milliequivalents of active oxygen per kilogram of oil (meqO ${ }_{2} \cdot \mathrm{kg}^{-1}$ oil); and the oxidation levels according to the UV absorption characteristics, as $K_{232}, K_{270}$ and $\lambda \mathrm{K}$. All of these parameters were determined according to the analytical methods described in the European Union Commission Regulation
EEC/2568/91 and its subsequent modifications. The analyses were carried out in duplicate for each sample. The chemical data are reported as means of two replicates. The data were subjected to one-way ANOVA and the differences compared with Fisher's tests at the 0.05 probability level.

\subsection{Fatty-acid composition}

The fatty acid composition of the oil was determined according to the method described in European Union Commission Regulation EEC/ 2568/91 and its subsequent modifications (Annex X.B). The procedure used a gas chromatography system (HRGC Mega 2 series 8560; Carlo Erba, Milan, Italy) equipped with an $\mathrm{SP}^{\mathrm{TM}}-2380$ (Supelco, Bellefonte, PA, USA) fused silica capillary column $(60 \mathrm{~m} \times 0.32 \mathrm{~mm}$ ID $\times 0.2 \mu \mathrm{m}$ film thickness). The oven temperature programme was from $70{ }^{\circ} \mathrm{C}$ to $165^{\circ} \mathrm{C}$ at $20^{\circ} \mathrm{C} \cdot \mathrm{min}^{-1}$ and held at $165^{\circ} \mathrm{C}$ for $23 \mathrm{~min}$; then from $165^{\circ} \mathrm{C}$ to $200{ }^{\circ} \mathrm{C}$ at $1.5^{\circ} \mathrm{C} \cdot \mathrm{min}^{-1}$ and held at $200{ }^{\circ} \mathrm{C}$ for $5 \mathrm{~min}$; and then from $200^{\circ} \mathrm{C}$ to $220^{\circ} \mathrm{C}$ at $2{ }^{\circ} \mathrm{C} \cdot \mathrm{min}^{-1}$ and held at $220^{\circ} \mathrm{C}$ for $5 \mathrm{~min}$. The detector temperature was $230^{\circ} \mathrm{C}$. Hydrogen was used as the carrier gas at a column head pressure of $60 \mathrm{kPa}$. The samples $(0.4 \mu \mathrm{L})$ were applied by on-column injection. The analysis was carried out in duplicate for each sample. The data were subjected to one-way ANOVA and the differences compared by Fisher's tests at the 0.05 probability level.

\subsection{Quantitative analysis of fatty-acid alkyl esters}

Fatty acid methyl esters (FAMEs) and fatty acid ethyl esters (FAEEs) were determined according to the method described in the European Union Commission Regulation EEC/2568/91 and its subsequent modifications (Annex XX). This procedure used the gas chromatography system (HRGC Mega 2 series 8560; Carlo Erba, Milan, Italy) equipped with a CP-Sil 5 CB Low Bleed/MS (Varian, USA) fused silica capillary column $(15 \mathrm{~m} \times 0.32 \mathrm{~mm}$ ID $\times 0.1 \mu \mathrm{m}$ film thickness). The oven temperature programme was $80^{\circ} \mathrm{C}$ for $1 \mathrm{~min}$, then from $80^{\circ}$ to $140{ }^{\circ} \mathrm{C}$ at $20^{\circ} \mathrm{C} \cdot \mathrm{min}^{-1}$, then from $140{ }^{\circ} \mathrm{C}$ to $340{ }^{\circ} \mathrm{C}$ at $5.0^{\circ} \mathrm{C} \cdot \mathrm{min}^{-1}$, then held at $340^{\circ} \mathrm{C}$ for $20 \mathrm{~min}$. The detector temperature was $350{ }^{\circ} \mathrm{C}$. Hydrogen was used as the carrier gas at a column head pressure of $80 \mathrm{kPa}$. The samples $(0.6 \mu \mathrm{L})$ were applied by oncolumn injection. The analysis was carried out in duplicate for each sample.

\subsection{Sensory evaluation of the end product}

The organoleptic characteristics of the olives were evaluated by tasters of the CREA-OLI Città Sant'Angelo Panel, according to COI/OT/MO No 1/Rev. 2. Method for the sensory analysis of table olives (IOC, 2011). The attributes evaluated were: 
(a) negative sensations (e.g., abnormal fermentation, such as butyric, putrid and zapateria, soapy, metallic, cooking effects, rancid, musty and earthy defects); (b) gustatory sensations (e.g., salty, bitter, acidic); and (c) kinaesthetic sensations (e.g., hardness, fibrousness, crunchiness). The table olive profile sheet uses a 10-point intensity scale that ranges from 1 (no perception) to 11 (extreme). To elaborate sensory data, the method applied was for the calculation of the median, the robust standard deviation $\left(\mathrm{s}^{*}\right)$, the robust coefficient of variation percentage $(\mathrm{CVr} \%)$, and the confidence intervals of the median at $95 \%\left(\mathrm{CI}_{\text {upper }}, \mathrm{C}_{\text {-lower }}\right)$, as in Annex 1 (COI/OT/ $\mathrm{MO} / \mathrm{n}^{\circ} 1 /$ Rev.2 Annex 1 Method for calculating the median and the confidence intervals), taking into account the attributes with a robust coefficient of variation of $20 \%$ or less. For classification purposes, only the median of the defect predominantly perceived (DPP) was considered. According to the DPP intensity, the olives were classified into one of four categories: (i) DPP $\leq 3$ : Extra or Fancy; (ii) $3<\mathrm{DPP} \leq 4.5$ : First or Select; (iii) $4.5<\mathrm{DPP} \leq 7.0$ : Second or Standard; (iv) DPP > 7.0: Olives that should not be sold as table olives.

\subsection{Multivariate analysis}

A hierarchical cluster analysis was carried out using the Past Paleontological Statistics software (version 2.12; Øyvind Hammer, Natural History Museum, University of Oslo, Norway).

\section{RESULTS AND DISCUSSION}

The evolution of the main oil chemical and physicochemical parameters related to quality is reported in Table 1. The free acidity showed a large increase due to the release of the free fatty acids from the lipids by hydrolysis. There are free fatty acids in olive oil due to the presence of endogenous lipase enzymes (Pereira et al., 2002) or lipase-producing microorganisms. Moreover, the presence of fatty acids acts as a catalyst for further production of free fatty acids. In olives processed according to the Greek style, the increase in free acidity was 15-fold and 32-fold for the 'Kalamata' and 'Moresca' cvs., respectively. For these olives, there were small but significant decreases in the spectrophotometric index calculated at $232 \mathrm{~nm}\left(\mathrm{~K}_{232}\right)$ and relatively large increases in the spectrophotometric index calculated at $270 \mathrm{~nm}\left(\mathrm{~K}_{270}\right)$ (Table 1). A similar trend was observed by Lopez-Lopez et al., 2009) in ripe table olives and Pasqualone et al., (2014) in natural olives. The oxidative phenomenon, and particularly that related to secondary oxidation, was more evident in the 'Moresca' olives, where a more marked increase in $\mathbf{K}_{270}$ was observed compared to the 'Kalamata' olives. Indeed, these $\mathbf{K}_{270}$ values exceeded the limits fixed for extra virgin olive oil ('Moresca' $\mathrm{K}_{270}$ : raw material, 0.11; processed material, 0.84; upper limit for extra virgin olive oil, 0.22). Similar trends have been observed in olives pitted and preserved in olive oil during storage (Lanza et al., 2013; Mucciarella and Marsilio, 1993).

The $\mathrm{K}_{232}, \mathrm{~K}_{270}$ and $\Delta \mathrm{K}$ indices for the olives processed as the Sevillan style remained essentially unaltered during the treatment, while there were smaller, but significant, increases in free acidity and peroxide value (Table 1).

The oil content remained constant for both processing styles (Table 1).

Table 2 shows the detailed fatty-acid composition of the oils extracted from the raw and processed olives, as relative percentages within the lipid fraction. Oleic acid was the predominant monounsaturated fatty acid ('Kalamata'> Nocellara del Belice'> 'Giarraffa'>'Moresca'), palmitic acid was the predominant saturated fatty acid ('Moresca'>'

TABLE 1. Oil quality indices and oil content. Data are means of two replicates, with all coefficients of variation $<5 \%$. For each variety, mean values within the same row followed by common superscript letters do not differ significantly $(\mathrm{P}<0.05)$

\begin{tabular}{|c|c|c|c|c|c|c|c|c|c|}
\hline \multirow[b]{2}{*}{ Quality indexes } & \multirow{2}{*}{$\begin{array}{c}\text { Range EVOO } \\
\text { Reg. UE } \\
\text { n.1348/2013 }\end{array}$} & \multicolumn{2}{|c|}{ Kalamata } & \multicolumn{2}{|c|}{ Moresca } & \multicolumn{2}{|c|}{ Giarraffa } & \multicolumn{2}{|c|}{ Nocellara del Belice } \\
\hline & & $\begin{array}{c}\text { Raw } \\
\text { material }\end{array}$ & $\begin{array}{c}\text { Natural } \\
\text { olives }\end{array}$ & $\begin{array}{c}\text { Raw } \\
\text { material }\end{array}$ & $\begin{array}{c}\text { Natural } \\
\text { olives }\end{array}$ & $\begin{array}{c}\text { Raw } \\
\text { material }\end{array}$ & $\begin{array}{c}\text { Alkaline-treated } \\
\text { olives }\end{array}$ & $\begin{array}{c}\text { Raw } \\
\text { material }\end{array}$ & $\begin{array}{l}\text { Alkaline- } \\
\text { treated olives }\end{array}$ \\
\hline $\begin{array}{l}\text { Free Acidity } \\
\left(\text { g oleic }^{-1}\right. \\
\left.\text { acid } 100 g^{-1} \text { oil }\right)\end{array}$ & $\leq 0.8$ & $1.2^{\mathrm{a}}$ & $17.7^{\mathrm{b}}$ & $0.8^{\mathrm{a}}$ & $25.5^{\mathrm{b}}$ & $0.8^{\mathrm{a}}$ & $2.3^{\mathrm{b}}$ & $1.4^{\mathrm{a}}$ & $1.9^{\mathrm{b}}$ \\
\hline $\begin{array}{l}\text { Peroxide value } \\
\left(\mathrm{meq} \cdot \mathrm{O}_{2} \mathrm{~kg}^{-1} \text { oil }\right)\end{array}$ & $\leq 20$ & $14^{\mathrm{a}}$ & $44^{\mathrm{b}}$ & $14^{\mathrm{a}}$ & $92^{\mathrm{b}}$ & $8^{\mathrm{a}}$ & $40^{\mathrm{b}}$ & $14^{\mathrm{a}}$ & $37^{\mathrm{b}}$ \\
\hline $\mathrm{K}_{232}$ & $\leq 2.50$ & $2.02^{\mathrm{a}}$ & $1.69^{\mathrm{b}}$ & $2.23^{\mathrm{a}}$ & $1.94^{\mathrm{b}}$ & $1.55^{\mathrm{a}}$ & $1.49^{\mathrm{a}}$ & $1.92^{\mathrm{a}}$ & $1.18^{\mathrm{b}}$ \\
\hline $\mathrm{K}_{270}$ & $\leq 0.22$ & $0.15^{\mathrm{a}}$ & $0.45^{\mathrm{b}}$ & $0.11^{\mathrm{a}}$ & $0.84^{\mathrm{b}}$ & $0.13^{\mathrm{a}}$ & $0.18^{\mathrm{b}}$ & $0.13^{\mathrm{a}}$ & $0.14^{\mathrm{a}}$ \\
\hline$\Delta \mathrm{K}$ & $\leq 0.01$ & $0.00^{\mathrm{a}}$ & $0.01^{\mathrm{b}}$ & $-0.01^{\mathrm{a}}$ & $0.03^{\mathrm{b}}$ & $0.00^{\mathrm{a}}$ & $0.00^{\mathrm{b}}$ & $-0.01^{\mathrm{a}}$ & $0.00^{\mathrm{b}}$ \\
\hline $\begin{array}{l}\text { oil content } \\
\left(\mathrm{g} \cdot 100 \mathrm{~g}^{-1} \text { of flesh }\right)\end{array}$ & & $18.2^{\mathrm{a}}$ & $18.2^{\mathrm{a}}$ & $21.8^{\mathrm{a}}$ & $22.4^{\mathrm{a}}$ & $9.0^{\mathrm{a}}$ & $10.1^{\mathrm{a}}$ & $20.1^{\mathrm{a}}$ & $19.5^{\mathrm{a}}$ \\
\hline
\end{tabular}


TABLE 2. Fatty acid compositions, as percentages. Data are means of two replicates, with all coefficients of variation $<5 \%$. For each variety, mean values within the same row followed by common superscript letters do not differ significantly $(\mathrm{P}<0.05)$

\begin{tabular}{|c|c|c|c|c|c|c|c|c|c|}
\hline \multirow[b]{2}{*}{ Fatty acid } & \multirow{2}{*}{$\begin{array}{c}\text { Range } \\
\text { EVOO } \\
\text { Reg. UE } \\
\text { n.1348/2013 }\end{array}$} & \multicolumn{2}{|c|}{ Kalamata } & \multicolumn{2}{|c|}{ Moresca } & \multicolumn{2}{|c|}{ Giarraffa } & \multicolumn{2}{|c|}{ Nocellara del Belice } \\
\hline & & $\begin{array}{c}\text { Raw } \\
\text { material }\end{array}$ & $\begin{array}{l}\text { Natural } \\
\text { olives }\end{array}$ & $\underset{\text { material }}{\text { Raw }}$ & $\begin{array}{l}\text { Natural } \\
\text { olives }\end{array}$ & $\underset{\text { material }}{\text { Raw }}$ & $\begin{array}{l}\text { Alkaline- } \\
\text { treated olives }\end{array}$ & $\begin{array}{c}\text { Raw } \\
\text { material }\end{array}$ & $\begin{array}{l}\text { Alkaline- } \\
\text { treated olives }\end{array}$ \\
\hline $\begin{array}{l}\text { Myristic acid } \\
\text { (C14:0) }\end{array}$ & $\leq 0.03$ & $0.03^{\mathrm{a}}$ & $0.01^{\mathrm{a}}$ & $0.01^{\mathrm{a}}$ & $0.01^{\mathrm{a}}$ & $0.00^{\mathrm{a}}$ & $0.01^{\mathrm{a}}$ & $0.01^{\mathrm{a}}$ & $0.01^{\mathrm{a}}$ \\
\hline $\begin{array}{l}\text { Palmitic acid } \\
\text { (C16:0) }\end{array}$ & $7.50-20.00$ & $10.13^{\mathrm{a}}$ & $9.10^{\mathrm{a}}$ & $15.73^{\mathrm{a}}$ & $15.13^{\mathrm{a}}$ & $13.26^{\mathrm{a}}$ & $15.38^{\mathrm{b}}$ & $10.89^{\mathrm{a}}$ & $13.62^{\mathrm{b}}$ \\
\hline $\begin{array}{l}\text { Ethyl palmitate } \\
\text { (C16:0-ethyl) }\end{array}$ & & $0.03^{\mathrm{a}}$ & $0.20^{\mathrm{b}}$ & $0.01^{\mathrm{a}}$ & $0.33^{\mathrm{b}}$ & $0.00^{\mathrm{a}}$ & $0.01^{\mathrm{a}}$ & $0.03^{\mathrm{a}}$ & $0.02^{\mathrm{a}}$ \\
\hline $\begin{array}{l}\text { cis-7 hexadecenoic acid } \\
\text { (C16:1 } \omega 9)\end{array}$ & & $0.10^{\mathrm{a}}$ & $0.10^{\mathrm{a}}$ & $0.13^{\mathrm{a}}$ & $0.10^{\mathrm{a}}$ & $0.18^{\mathrm{a}}$ & $0.06^{\mathrm{a}}$ & $0.10^{\mathrm{a}}$ & $0.10^{\mathrm{a}}$ \\
\hline $\begin{array}{l}\text { Palmitoleic acid (C16:1 } \\
\text { (7) }\end{array}$ & $0.30-3.50$ & $0.79^{\mathrm{a}}$ & $0.83^{\mathrm{a}}$ & $2.26^{\mathrm{a}}$ & $2.93^{\mathrm{a}}$ & $1.12^{\mathrm{a}}$ & $0.80^{\mathrm{a}}$ & $0.85^{\mathrm{a}}$ & $1.11^{\mathrm{a}}$ \\
\hline $\begin{array}{l}\text { Heptadecanoic acid } \\
\text { (C17:0) }\end{array}$ & $\leq 0.30$ & $0.08^{\mathrm{a}}$ & $0.11^{\mathrm{a}}$ & $0.12^{\mathrm{a}}$ & $0.10^{\mathrm{a}}$ & $0.13^{\mathrm{a}}$ & $0.12^{\mathrm{a}}$ & $0.03^{\mathrm{a}}$ & $0.03^{\mathrm{a}}$ \\
\hline $\begin{array}{l}\text { Heptadecenoic acid } \\
\text { (C17:1 } \omega 7)\end{array}$ & $\leq 0.30$ & $0.23^{\mathrm{a}}$ & $0.27^{\mathrm{a}}$ & $0.33^{\mathrm{a}}$ & $0.32^{\mathrm{a}}$ & $0.30^{\mathrm{a}}$ & $0.22^{\mathrm{a}}$ & $0.07^{\mathrm{a}}$ & $0.07^{\mathrm{a}}$ \\
\hline $\begin{array}{l}\text { Stearic acid } \\
(\mathrm{C} 18: 0)\end{array}$ & $0.50-5.00$ & $1.67^{\mathrm{a}}$ & $1.32^{\mathrm{b}}$ & $1.75^{\mathrm{a}}$ & $1.63^{\mathrm{b}}$ & $1.86^{\mathrm{a}}$ & $1.96^{\mathrm{a}}$ & $2.95^{\mathrm{a}}$ & $2.56^{\mathrm{a}}$ \\
\hline $\begin{array}{l}\text { Oleic acid } \\
(\mathrm{C} 18: 1 \omega 9)\end{array}$ & $55.00-83.00$ & $78.66^{\mathrm{a}}$ & $77.31^{b}$ & $67.04^{\mathrm{a}}$ & $63.38^{\mathrm{b}}$ & $72.91^{\mathrm{a}}$ & $73.00^{\mathrm{a}}$ & $75.51^{\mathrm{a}}$ & $74.17^{\mathrm{a}}$ \\
\hline $\begin{array}{l}\text { Ethyl oleate } \\
\text { (C18:1-ethyl) }\end{array}$ & & $0.26^{\mathrm{a}}$ & $1.20^{\mathrm{b}}$ & $0.01^{\mathrm{a}}$ & $0.98^{\mathrm{b}}$ & $0.00^{\mathrm{a}}$ & $0.04^{\mathrm{a}}$ & $0.24^{\mathrm{a}}$ & $0.11^{\mathrm{a}}$ \\
\hline $\begin{array}{l}\text { Linoleic acid } \\
(\mathrm{C} 18: 2 \omega 6)\end{array}$ & $3.50-21.00$ & $6.87^{\mathrm{a}}$ & $8.15^{\mathrm{b}}$ & $11.24^{\mathrm{a}}$ & $13.60^{\mathrm{b}}$ & $8.42^{\mathrm{a}}$ & $6.58^{\mathrm{b}}$ & $7.87^{\mathrm{a}}$ & $6.67^{\mathrm{b}}$ \\
\hline $\begin{array}{l}\text { Ethyl linoleate } \\
\text { (C18:2-ethyl) }\end{array}$ & & $0.02^{\mathrm{a}}$ & $0.18^{\mathrm{b}}$ & $0.01^{\mathrm{a}}$ & $0.31^{\mathrm{b}}$ & $0.01^{\mathrm{a}}$ & $0.02^{\mathrm{a}}$ & $0.00^{\mathrm{a}}$ & $0.00^{\mathrm{a}}$ \\
\hline Arachidic acid (C20:0) & $\leq 0.60$ & $0.26^{\mathrm{a}}$ & $0.21^{\mathrm{a}}$ & $0.30^{\mathrm{a}}$ & $0.26^{\mathrm{a}}$ & $0.33^{\mathrm{a}}$ & $0.39^{\mathrm{a}}$ & $0.41^{\mathrm{a}}$ & $0.39^{\mathrm{a}}$ \\
\hline $\begin{array}{l}\text { Linolenic acid } \\
(\mathrm{C} 18: 3 \omega 3)\end{array}$ & $\leq 1.00$ & $0.58^{\mathrm{a}}$ & $0.64^{\mathrm{a}}$ & $0.69^{\mathrm{a}}$ & $0.65^{\mathrm{a}}$ & $0.96^{\mathrm{a}}$ & $0.96^{\mathrm{a}}$ & $0.67^{\mathrm{a}}$ & $0.78^{\mathrm{a}}$ \\
\hline $\begin{array}{l}\text { Eicosenoic acid (C20:1 } \\
\omega 9)\end{array}$ & $\leq 0.40$ & $0.25^{\mathrm{a}}$ & $0.29^{\mathrm{a}}$ & $0.24^{\mathrm{a}}$ & $0.19^{\mathrm{a}}$ & $0.32^{\mathrm{a}}$ & $0.32^{\mathrm{a}}$ & $0.25^{\mathrm{a}}$ & $0.26^{\mathrm{a}}$ \\
\hline Behenic acid (C22:0) & $\leq 0.20$ & $0.06^{\mathrm{a}}$ & $0.05^{\mathrm{a}}$ & $0.08^{\mathrm{a}}$ & $0.06^{\mathrm{a}}$ & $0.10^{\mathrm{a}}$ & $0.11^{\mathrm{a}}$ & $0.08^{\mathrm{a}}$ & $0.09^{\mathrm{a}}$ \\
\hline Lignoceric acid (C24:0) & $\leq 0.20$ & $0.02^{\mathrm{a}}$ & $0.02^{\mathrm{a}}$ & $0.04^{\mathrm{a}}$ & $0.02^{\mathrm{a}}$ & $0.08^{\mathrm{a}}$ & $0.02^{\mathrm{a}}$ & $0.03^{\mathrm{a}}$ & $0.01^{\mathrm{a}}$ \\
\hline
\end{tabular}

Giarraffa'>'Nocellara del Belice', 'Kalamata'), and linoleic and linolenic acids were the most abundant polyunsaturated fatty acids. These patterns are largely common to most of the data in the literature (Lanza et al., 2010; Sakouhi et al., 2008; López et al., 2006; López-López et al., 2010; Issaoui et al., 2011; Dugo et al., 2004; Lo Curto et al., 2002).

In the 'Kalamata' and 'Moresca' olives that were processed according to the Greek style, through processing, oleic acid decreased and linoleic acid increased with respect to the raw materials (Table 2). At the same time, there was the appearance of the respective ethyl esters, as principally ethyl oleate ('Kalamata', 1.2\%; 'Moresca', 1.0\%; Table 2). The fatty acid alkyl esters, as the FAMEs and FAEEs, are formed by esterification of free fatty acids with shortchain alcohols (i.e., with from one to four carbon atoms), with mainly methanol and ethanol yielding their methyl and ethyl esters, respectively (PérezCamino et al., 2002). The alkyl esters originate mainly from incorrect farming practices and technology use, especially in terms of the fermentation and degradation of over-ripe olives, or olives that were damaged or stored under less than ideal conditions before being processed. Oils, obtained by olives that have undergone these fermentation processes, often have a high content of alkyl esters and show organoleptic defects like 'fusty/ muddy' and 'winey', and also 'musty' (GómezCoca et al., 2012). 
In the natural olives processed by the Greek system, when the $\mathrm{pH}$ reaches about 6.0, the Gramnegative microorganisms progressively decrease, until they disappear altogether. The reducing sugars and glucosides represent the basic sources of carbon needed for the development of lactobacilli and other microorganisms, and these pass from the olive flesh into the brine. They are then used by hetero-fermentative or homo-fermentative microorganisms that transform them into lactic acid, ethanol and $\mathrm{CO}_{2}$ (Figure 1). Most of the microorganisms that grow in this first brine are lattococci, of the genera Pediococcus (homo-fermentative strains) and Leuconostoc (hetero-fermentative strains). These produce lactic acid, which contributes to further lowering of the $\mathrm{pH}$. This then favours the growth of lactic acid bacteria, which are aciduric, with their optimal growth between $\mathrm{pH} 5.5$ and $\mathrm{pH}$ 5.8. This phase is characterized by an abundant growth of homo-fermentative lactobacilli, with a predominance of Lactobacillus plantarum. A population of yeast with fermentative metabolism can then co-exist with the lactic acid bacteria. These microorganisms produce ethanol, $\mathrm{CO}_{2}$ and secondary compounds through alcoholic fermentation. The lactic fermentation ends when the supply of available carbohydrates is exhausted.

At the end of this phase, if the product is not pasteurized, during storage it can undergo a further unwanted fermentation stage, with the development of propionibacteria, clostridia, yeast and acetic bacteria. These can metabolize the lactic acid, to produce propionic acid, butyric acid, acetic acid and ethanol (Figure 1). If these microorganisms do not become prevalent, they are not considered to be harmful to the process. On the contrary, abnormal fermentation causes the production of malodorous compounds responsible for the defects (Lanza, 2013). In our natural olives, the $\mathrm{pH}$ at the end of fermentation period reached 5.2 \pm 0.1 (for Kalamata olives) and 5.5 \pm 0.2 (for Moresca olives).

In the olives processed according to the Greek style, the sensory analysis showed the presence of defects related to abnormal fermentation, including 'putrid-butyric fermentation', and 'winey-vinegary' (Table 3). Winey-vinegary is an olfactory-gustatory sensation that is reminiscent of wine or vinegar, due to the high production of ethanol, acetic acid, 3-methyl butanol, and ethyl acetate. The ethanol produced during abnormal fermentation and a high free acidity (Table 1) probably results in the formation of FAEEs (Tables 2, 4). Indeed, ethyl palmitate, ethyl oleate, ethyl linoleate, and ethyl stearate are fatty acid esters that are formed by condensation of their corresponding fatty acids (i.e. palmitic, oleic, linoleic, stearic acids) and ethanol. 'Kalamata' and 'Moresca' showed very high levels of ethyl oleate and linoleate $\left(4764\right.$ and $4195 \mathrm{mg} \cdot \mathrm{kg}^{-1}$ oil, respectively) and ethyl palmitate (617 and $886 \mathrm{mg} \cdot \mathrm{kg}^{-1}$ oil, respectively).

In plant cells, this reaction is catalyzed by wax synthase (WS)/ acyl-coenzyme A: diacylglycerol acyltransferase (WS/DGAT), and this appears to happen also in these olives (Figure 1). There are

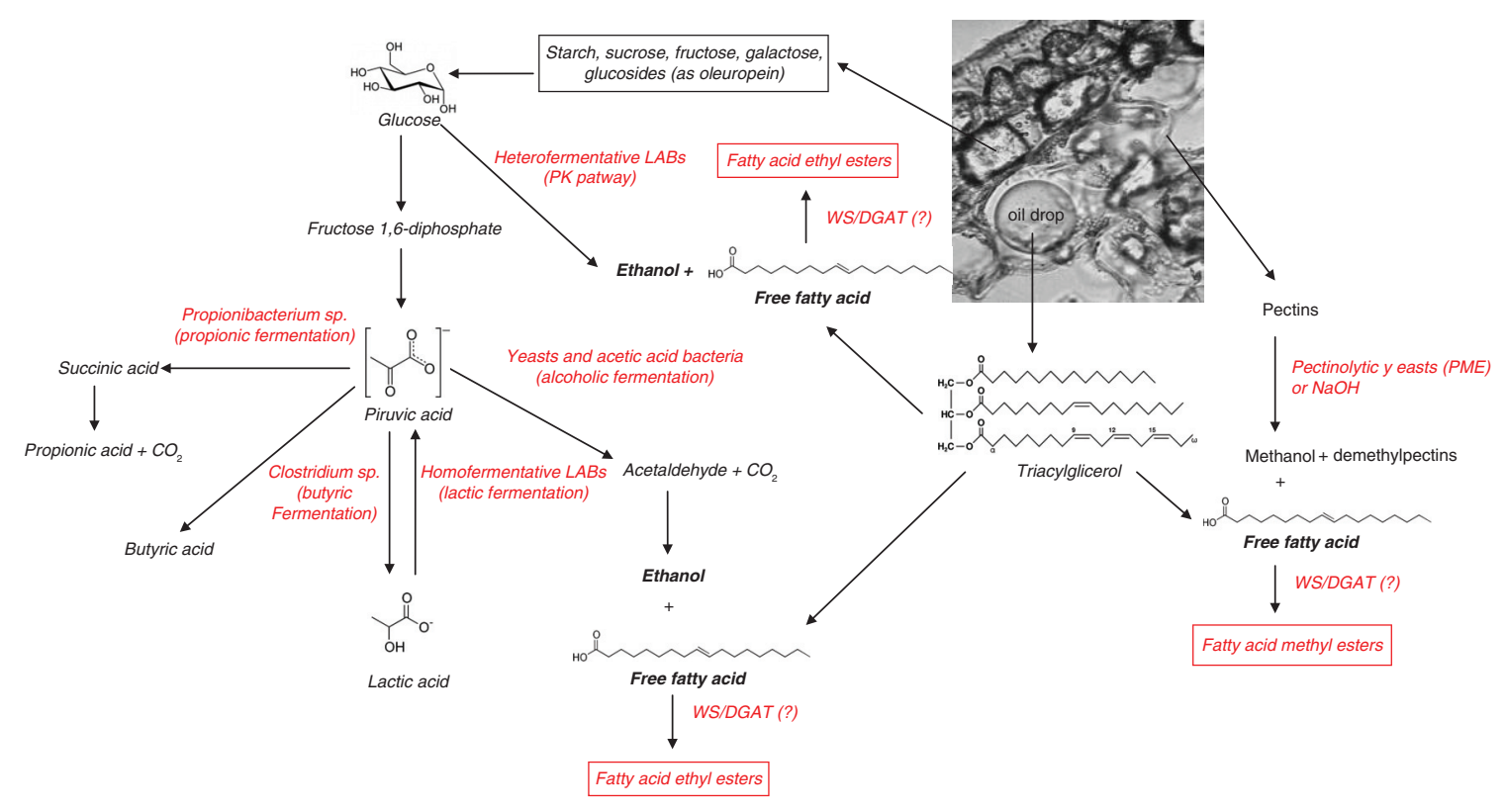

FIGURE 1. Carbohydrate metabolism and fatty-acid alkyl ester formation pathways in table olives. 
Fatty-acid alkyl esters in table olives in relation to abnormal fermentation and poorly conducted technological treatments $\mathbf{7}$

TABLE 3. Sensory evaluation of table olives. $\mathrm{S}^{*}$, standard deviation; $\mathrm{CVr} \%$, coefficient of variation percentage; CI, confidence interval

\begin{tabular}{|c|c|c|c|c|c|c|c|c|c|}
\hline \multirow[b]{2}{*}{ Cultivar } & \multirow[b]{2}{*}{ Statistics } & \multicolumn{8}{|c|}{ Organoleptic sensations } \\
\hline & & $\begin{array}{c}\text { Abn. } \\
\text { fermentation } \\
\text { (putrid-butyric) }\end{array}$ & $\begin{array}{l}\text { Other defects } \\
\text { (winey- } \\
\text { vinegar) }\end{array}$ & Salty & Bitter & Acidic & Hardness & Fibrousness & Crunchiness \\
\hline \multirow[t]{6}{*}{ Kalamata } & Median & 2.5 & 2.0 & 5.6 & 4.4 & 2.7 & 5.5 & 5.0 & 5.7 \\
\hline & $\mathrm{S}^{*}$ & 0.5 & 0.5 & 0.6 & 0.2 & 0.4 & 0.8 & 1.0 & 0.2 \\
\hline & $\mathrm{CVr} \%$ & 18.5 & 23.2 & 9.9 & 3.5 & 13.7 & 15.2 & 19.8 & 3.8 \\
\hline & CI Upper & 3.4 & 2.9 & 6.7 & 4.7 & 3.4 & 7.1 & 6.9 & 6.1 \\
\hline & CI Lower & 1.6 & 1.1 & 4.5 & 4.1 & 2.0 & 3.9 & 3.1 & 5.3 \\
\hline & Classification & EXTRA & & & & & & & \\
\hline \multirow[t]{6}{*}{ Moresca } & Median & 3.3 & 3.0 & 5.4 & 3.9 & 4.3 & 3.3 & 3.4 & 5.0 \\
\hline & $\mathrm{S}^{*}$ & 0.6 & 0.8 & 0.7 & 0.4 & 0.6 & 0.2 & 0.3 & 0.2 \\
\hline & $\mathrm{CVr} \%$ & 18.7 & 25.7 & 12.6 & 10.3 & 14.4 & 4.7 & 7.3 & 4.3 \\
\hline & CI Upper & 4.5 & 4.5 & 6.7 & 4.7 & 5.5 & 3.6 & 3.9 & 5.4 \\
\hline & CI Lower & 2.1 & 1.5 & 4.1 & 3.1 & 3.1 & 3.0 & 2.9 & 4.6 \\
\hline & Classification & FIRST & & & & & & & \\
\hline \multirow[t]{6}{*}{ Giarraffa } & Median & 1.0 & 1.0 & 5.8 & 3.9 & 4.1 & 5.6 & 4.7 & 6.3 \\
\hline & $\mathrm{S}^{*}$ & 0.0 & 0.0 & 0.3 & 0.8 & 0.4 & 0.6 & 0.8 & 0.2 \\
\hline & $\mathrm{CVr} \%$ & 0.0 & 0.0 & 4.3 & 19.5 & 10.6 & 10.2 & 18.1 & 2.9 \\
\hline & CI Upper & 1.0 & 1.0 & 6.2 & 5.4 & 5.0 & 6.7 & 6.3 & 6.6 \\
\hline & CI Lower & 1.0 & 1.0 & 5.3 & 2.4 & 3.2 & 4.4 & 3.0 & 5.9 \\
\hline & Classification & EXTRA & & & & & & & \\
\hline \multirow[t]{6}{*}{ Nocellara del Belice } & Median & 1.0 & 2.3 & 4.0 & 2.5 & 2.6 & 4.2 & 3.8 & 4.5 \\
\hline & $\mathrm{S}^{*}$ & 0.0 & 0.6 & 0.3 & 0.3 & 0.3 & 0.5 & 0.7 & 0.1 \\
\hline & $\mathrm{CVr} \%$ & 0.0 & 24.2 & 7.7 & 13.6 & 9.5 & 11.0 & 18.7 & 2.7 \\
\hline & CI Upper & 1.0 & 3.4 & 4.6 & 3.2 & 3.1 & 5.1 & 5.2 & 4.7 \\
\hline & CI Lower & 1.0 & 1.2 & 3.4 & 1.8 & 2.1 & 3.3 & 2.4 & 4.3 \\
\hline & Classification & EXTRA & & & & & & & \\
\hline
\end{tabular}

TABLE 4. Fatty acid alkyl esters in table olives. Data are $\mathrm{mg} \cdot \mathrm{kg}^{-1}$ oil, as means of two replicates ( \pm standard deviation)

\begin{tabular}{lccccc}
\hline \multirow{2}{*}{ Alkyl esters } & \multicolumn{2}{c}{ Natural olives } & & \multicolumn{2}{c}{ Alkaline-treated olives } \\
\cline { 2 - 3 } \cline { 5 - 6 } FAME-palmitate & Kalamata & Moresca & & Giarraffa & Nocellara del Belice \\
FAME-oleate, FAME-linoleate & $74 \pm 2$ & $100 \pm 3$ & & $15 \pm 1$ & $7 \pm 2$ \\
FAME-stearate & $553 \pm 14$ & $450 \pm 2$ & & $30 \pm 2$ & $44 \pm 7$ \\
FAEE-palmitate & $2 \pm 0$ & $4 \pm 1$ & & $1 \pm 0$ & $1 \pm 0$ \\
FAEE-oleate, FAEE-linoleate & $617 \pm 9$ & $886 \pm 12$ & & $65 \pm 2$ & $51 \pm 3$ \\
FAEE-stearate & $4764 \pm 31$ & $4195 \pm 40$ & & $222 \pm 20$ & $289 \pm 10$ \\
FAMEs & $85 \pm 4$ & $84 \pm 2$ & & $4 \pm 1$ & $24 \pm 2$ \\
FAEEs & $629 \pm 12$ & $553 \pm 15$ & & $46 \pm 2$ & $52 \pm 4$ \\
Total alkyl esters & $5466 \pm 25$ & $5165 \pm 32$ & & $291 \pm 15$ & $364 \pm 17$ \\
\hline
\end{tabular}

four types of WS enzymes that are known to catalyze wax ester formation. The first type, the mammalian WS enzymes, have the highest activities with acyl-CoAs between $\mathrm{C} 12$ and C16 in length, and they efficiently use alcohols shorter than C20 (Cheng and Russell, 2004). These enzymes have no obvious orthologues in plants. The second type, the jojoba WS, uses a wide range of saturated and unsaturated 
acyl-CoAs ranging from $\mathrm{C} 14$ to $\mathrm{C} 24$, with $\mathrm{C} 20: 1$ as the preferred substrate, and it shows the highest activity with C18:1 alcohol (Lardizabal et al., 2000). The third type is the Acinetobacter calcoaceticus WS enzyme, which shows both WS activity and DGAT activity. This bi-functional protein is unrelated to the mammalian or jojoba WS enzymes, and it shows preference for C14 and C16 acyl-CoA, together with C14 to C18 alcohols (Kalscheuer and Steinbuchel, 2003; Stoveken et al., 2005). Finally Li et al. (2008) described the WS/DGAT enzyme that catalyzes the biosynthesis of wax esters in Arabidopsis. This enzyme is located in the endoplasmic reticulum, and for its wax ester production it uses long-chain and very-long-chain primary alcohols with $\mathrm{C} 16$ fatty acid.

Duan et al. (2011) reported the de-novo biosynthesis of FAEEs from glucose. FAEEs can be derived from the lignocellulosic biomass during the production of biodiesel by genetically engineered Escherichia coli, through the introduction of the ethanol-producing pathway from Zymomonas mobilis, genetic manipulation to increase the pool of fatty acyl-CoA, and heterologous expression of WS/ DGAT from Acinetobacter baylyi. An optimized batch-fed microbial fermentation of the modified E. coli strain yielded a titer of $922 \mathrm{mg} \cdot \mathrm{L}^{-1}$ FAEEs that consisted primarily of ethyl palmitate, oleate, myristate and palmitoleate.

Ethyl oleate is also one of the FAEEs that is formed in the body after the ingestion of ethanol. There is a growing body of research literature that implicates FAEEs, such as ethyl oleate, as toxic mediators of ethanol in the body (e.g., in pancreas, liver, heart, brain) (Laposata, 1998). The oral ingestion of ethyl oleate has been carefully studied, and due to its rapid degradation in the digestive tract, it appears safe for oral ingestion (Saghir, 1997).

During the first phase of the fermentation process, there is the development of pectinolytic yeast and moulds that are associated with the 'softening' of the fruit (e.g., Saccharomyces oleaginosus, Saccharomyces kluyveri, Hansenula anomala, Pichia manshurica, Pichia kudriavzevii, Candida boidinii, Rhodotorula minuta, Rhodotorula rubra, Rhodotorula glutinis, Aspergillus niger, Penicillium sp., Fusarium sp.). This is due to the action of their degrading enzymes, such as pectin methylesterase (EC. 3.1.1.11), that act on the pectic substances that form the middle lamella, which leads to cell separation (Lanza, 2013; Golomb et al., 2013; ArroyoLópez et al., 2008. The demethylation of pectins produces methanol (Figure 1), which probably causes the appearance of FAMEs. Indeed, methyl palmitate, methyl oleate, methyl linoleate and methyl stearate are fatty acid esters that are formed by the condensation of their corresponding fatty acids (i.e., palmitic, oleic, linoleic, stearic acids) and methanol. 'Kalamata' and 'Moresca' showed high levels of methyl oleate and linoleate (553 and $450 \mathrm{mg} \cdot \mathrm{kg}^{-1}$ oil, respectively).

Softening of the fruit was also observed in olives treated with lye $(\mathrm{NaOH})$, where the degradation of the pectins is due to alkaline hydrolysis (Marsilio et al., 1996). In the 'Giarraffa' and 'Nocellara del Belice' olives processed according to the Sevilian style, palmitic acid increased and linoleic acid decreased, while oleic and stearic acids remained unaltered, with respect to the raw materials (Table 2). We observed the appearance of lower concentrations of the respective methyl and ethyl esters compared with the fermented olives (Table 4). There was only an appreciable amount of ethyl oleate and linoleate (222 and $289 \mathrm{mg} \cdot \mathrm{kg}^{-1}$ oil, respectively; Table 4 ). The sensory analysis revealed the presence of the 'soapy' defect in 'Nocellara del Belice', due to the residual lye after de-bittering (Table 3). Soapy is an olfactory-gustatory sensation that is reminiscent of soap. This taste is found primarily in olives treated with lye (i.e., the Sevilian and Castelvetrano styles) that are not sufficiently rinsed with water or are consumed shortly after de-bittering.

The changes in table olive lipid fractions were also studied using multivariate statistical approaches to identify similarities and differences between cultivars and processing. The entire data matrix included only the parameters that underwent statistically significant changes, and these were subjected to hierarchical cluster analysis. The dendrogram obtained is shown in Figure 2, where it can be seen that for the considered parameters, the
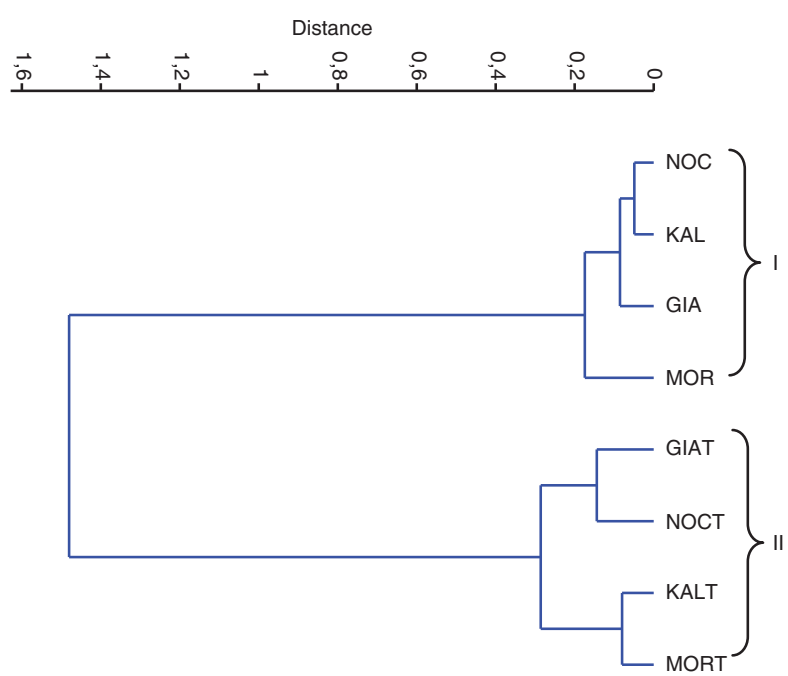

FIGURE 2. Dendrogram obtained using the paired group algorithm and the Euclidean similarity measure. KAL and KALT ('Kalamata' raw and natural olives, respectively); MOR and MORT ('Moresca' raw and natural olives, respectively); GIA and GIAT ('Giarraffa' raw and alkaline-treated olives, respectively); NOC and NOCT ('Nocellara del Belice' raw and alkaline-treated olives, respectively). 
four olive cultivars were clustered into two major clusters (I and II). Cluster I was comprised of raw fruit, while Cluster II was the processed fruit. Cluster II also shows two sub-clusters, according to the different processing technologies investigated here.

\section{CONCLUSIONS}

In olives processed according to the Greek style, poorly conducted technological treatments, such as the low concentration of brine, can influence the lipid fraction of the fruit, which results in the insurgence of defects (as revealed by sensory analysis) and the production of FAMEs and FAEEs of palmitic, oleic, linoleic and stearic acids. These appear to be due to the actions of the microflora involved in the fermentation processes and with fruit softening. In the olives processed according to the Sevilian style, poorly conducted technological treatments, in terms of the high $\mathrm{NaOH}$ concentration, influence the fatty acid composition to a lesser degree, but as the residual lye is difficult to eliminate, the olives had a soapy defect. The hierarchical cluster analysis grouped samples according to their processing.

\section{ACKNOWLEDGEMENTS}

This study was supported partial grants from the BIODATI Project (D.M. MIPAAF 15421/7303/11).

\section{REFERENCES}

Arroyo-López FN, Querol A, Bautista-Gallego J, GarridoFernández A. 2008. Role of yeasts in table olive production. Int. J. Food Microbiol. 128, 189-196. http://dx.doi. org/10.1016/j.ijfoodmicro.2008.08.018.

Baiano A, Gambacorta G, Terracone C. Previtali MA, La Notte E. 2009. Characteristics of drupes, phenolic content and antioxidant capacity of Italian olive fruits. J. Food Lipids. 16, 209226. http://dx.doi.org/10.1111/j.1745-4522.2009.01142.x.

Balatsouras G. 1990. Edible olive cultivars, chemical composition of fruit, harvesting, transportation, processing, sorting and packaging, styles of black olives, deteriorations, quality standards, chemical analyses, nutritional and biological value of the product. In Proceedings of International Seminar "Olio d'oliva e olive da tavola: tecnologia e qualità", Citta Sant'Angelo, Italy.

Boskou G, Salta FN, Chrysostomou S, Mylona A, Chiou A, Andrikopoulos NK. 2006. Antioxidant capacity and phenolic profile of table olives from the Greek market. Food Chem. 94, 558-564. http://dx.doi.org/10.1016/j. foodchem.2004.12.005.

Cheng JB, Russell DW. 2004. Mammalian wax biosynthesis. 2 . Expression cloning of wax synthase cDNAs encoding a member of the acyltransferase enzyme family. J. Biol. Chem. 279, 37798-37807. http://dx.doi.org/10.1074/jbc. M406226200.

Duan Y, Zhu Z, Cai K, Tan X, Lu X. 2011. De-novo biosynthesis of biodiesel by Escherichia coli in optimized fed-batch cultivation. PLoS ONE. 6, e20265. http://dx.doi.org/10.1371/ journal.pone. 0020265 .

Dugo G, Alfa M, La Pera L, Mavrogeni E, Pollicino D, Maisano R, Pizzimenti G. 2004. Characterization of Sicilian virgin olive oils. Note X. A comparison between Cerasuola and
Nocellara del Belice varieties. Grasas Aceites. 55, 415-422. http://dx.doi.org/10.3989/gya.2004.v55.i4.209.

Garrido Fernandez A, Fernandez Diez MJ, Adams MR. 1997. Table Olives. Production and processing. Chapman \& Hall, London.

Golomb BL, Morales V, Jung A, Yau B, Boundy-Mills KL, Marco ML. 2013. Effects of pectinolytic yeast on the microbial composition and spoilage of olive fermentations. Food Microbiol. 33, 97-106. http://dx.doi.org/10.1016/j. fm.2012.09.004

Gómez-Coca RB, Moreda W, Pérez-Camino MC. 2012. Fatty acid alkyl esters presence in olive oil vs. organoleptic assessment. Food Chem. 135, 1205-1209. http://dx.doi. org/10.1016/j.foodchem.2012.05.053.

IOC. 2004. Trade standard applying to table olives COI/OT/ NC No 1 December 2004, International Olive Oil Council, Madrid

IOC. 2011. Method for the sensory analysis of table olives COI/OT/MO/Doc. No 1/Rev. 2, International Olive Oil Council, Madrid

Issaoui M, Dabbou S, Mechri B, Nakbi A, Chehab H, Hammami M. 2011. Fatty acid profile, sugar composition, and antioxidant compounds of table olives as affected by different treatments. Eur. Food Res. Technol. 232, 867-876. http:// dx.doi.org/10.1007/s00217-011-1455-3.

Kalscheuer R, Steinbuchel A. 2003. A novel bifunctional wax ester synthase/ acyl-CoA:diacylglycerol acyltransferase mediates wax ester and triacylglycerol biosynthesis in Acinetobacter calcoaceticus ADP1. J. Biol. Chem. 278, 8075-8082. http://dx.doi.org/10.1074/jbc.M210533200

Lanza B, Di Serio MG, Giansante L, Di Loreto G, Russi F, Di Giacinto L. 2013. Effect of pasteurization and storage on quality characteristics of table olives preserved in olive oil. Int. J. Food Sci. Tech. 48, 2630-2637. http://dx.doi. org/10.1111/ijfs.12259.

Lanza B, Di Serio MG, Iannucci E, Russi F, Marfisi P. 2010. Nutritional, textural and sensorial characterisation of Italian table olives (Olea europaea L. cv. 'Intosso d'Abruzzo'). Int. J. Food Sci. Tech. 45, 67-74. http://dx.doi. org/10.1111/j.1365-2621.2009.02104.x.

Lanza B. 2013. Abnormal fermentations in table-olive processing: microbial origin and sensory evaluation. Front. Microbiol. 4,1-7. http://dx.doi.org/10.3389/fmicb.2013.00091.

Laposata M. 1998. Fatty acid ethyl esters: nonoxidative metabolites of ethanol. Addict. Biol. 3, 5-14. http://dx.doi. org/10.1080/13556219872308.

Lardizabal KD, Metz JG, Sakamoto T, Hutton WC, Pollard MR, Lassner MW. 2000. Purification of a jojoba embryo wax synthase, cloning of its cDNA, and production of high levels of wax in seeds of transgenic Arabidopsis. Plant Physiol. 122, 645-656. http://dx.doi. org/10.1104/pp.122.3.645.

Li F, Wu X, Lam P, Bird D, Zheng H, Samuels L, Jetter R, Kunst L. 2008. Identification of the wax ester synthase/ acyl-Coenzyme A:diacylglycerol acyltransferase WSD1 required for stem wax ester biosynthesis in Arabidopsis. Plant Physiol. 148, 97-107. http://dx.doi.org/10.1104/pp.108.123471

Lo Curto S, Salvo F, La Torre L, Dugo G, Pizzimenti G, Maisano R. 2002. Caratterizzazione di oli di oliva vergini sicilianiNota VIII. L'olio delle varietà Tonda Iblea e Moresca. Riv. Ital. Sostanze Gr. 79, 21-32.

López A, Montaño A, Garcia P, Garrido A. 2006. Fatty acid profile of table olives and its multivarate characterization using unsupervised (PCA) and supervised (DA) chemometrics. J. Agr. Food Chem. 54, 6747-6753. http://dx.doi. org/10.1021/jf0612474.

López-López A, Montaño A, Garrido-Fernández A. 2010. Nutrient profiles of commercial table olives: fatty acids, sterols, and fatty alcohols. In Olives and olive oil in health and disease prevention, ed. by Preedy VR and Watson RR, Elsevier, San Diego, pp. 715-723.

López-López A, Rodríguez-Gómez F, Cortés-Delgado A, Montano A, Garrido-Fernández A. 2009. Influence of ripe table olive processing on oil characteristics and composition as determined by chemometrics. J. Agr. Food Chem. 57, 8973-8981. http://dx.doi.org/10.1021/jf901488h. 
Malheiro R, Casal S, Sousa A, de Pinho PG, Peres AM, Dias LG, Bento A, Pereira JA. 2012. Effect of cultivar on sensory characteristics, chemical composition, and nutritional value of stoned green table olives. Food Bioprocess Tech. 5, 1733-1742. http://dx.doi.org/10.1007/s11947-011-0567-x.

Marsilio V, Lanza B, De Angelis M. 1996. Olive cell wall components: physical and biochemical changes during processing. J. Sci. Food Agric. 70, 35-43.

Mucciarella MR, Marsilio V. 1993. Influenza del processo tecnologico di preparazione e della conservazione sulle caratteristiche chimico-fisiche dell'olio di oliva vergine extra usato come copertura di conserve vegetali in vasetti di vetro. Riv. Ital. Sostanze Gr. 74, 105-112.

Pasqualone A, Nasti R, Montemurro C, Gomes T. 2014. Effect of natural-style processing on the oxidative and hydrolytic degradation of the lipid fraction of table olives. Food Cont. 37, 99-103. http://dx.doi.org/10.1016/j.foodcont. 2013.09.038.

Pereira JA, Casal S, Bento A, Oliveira MB. 2002. Influence of olive storage period on oil quality of three Portuguese cultivars of Olea europea, Cobrançosa, Madural, and Verdeal Transmontana. J. Agr. Food Chem. 50, 6335-6340. http:// dx.doi.org/10.1021/jf011661y.
Pérez-Camino MC, Moreda W, Mateos R, Cert A. 2002. Determination of esters of fatty acids with low molecular weight alcohols in olive oils. J. Agr. Food Chem. 50, 4721-4725. http://dx.doi.org/10.1021/jf025542+.

Saghir M. 1997. Rapid in-vivo hydrolysis of fatty acid ethyl esters, toxic nonoxidative ethanol metabolites. Am. J. Physiol. 273, G184-190.

Sakouhi F, Harrabi S, Absalon C, Sbei K, Boukhchina S, Kallel H. 2008. $\alpha$-Tocopherol and fatty acids contents of some Tunisian table olives (Olea europaea L.): changes in their composition during ripening and processing. Food Chem. 108, 833-839. http://dx.doi.org/10.1016/j. foodchem.2007.11.043

Sánchez Gómez AH, García García P, Rejano Navarro L. 2006. Elaboration of table olives. Grasas Aceites. 57, 86-94. http://dx.doi.org/10.3989/gya.2006.v57.i1.24.

Stoveken T, Kalscheuer R, Malkus U, Reichelt R, Steinbuchel A. 2005. The wax ester synthase/acyl Coenzyme A: diacylglycerol acyltransferase from Acinetobacter sp. strain ADP1: characterization of a novel type of acyltransferase. J. Bacteriol. 187, 1369-1376. http://dx.doi.org/10.1128/ JB.187.4.1369-1376.2005. 